DIGITAL COMMONS
@ UNIVERSITY OF SOUTH FLORIDA

Journal of African Conflicts and

Peace Studies

Volume 3

Issue 2 Organizations \& Institutions in the

Peace Process

June 2017

\title{
Role of Civil Society Organizations in Conflict and Post-Conflict Situations in Rwanda
}

Masabo Francois

University of Rwanda, masabofr@yahoo.fr

Follow this and additional works at: https://digitalcommons.usf.edu/jacaps

Part of the Sociology of Culture Commons

\section{Recommended Citation}

Francois, Masabo (2017) "Role of Civil Society Organizations in Conflict and Post-Conflict Situations in Rwanda," Journal of African Conflicts and Peace Studies: Vol. 3: Iss. 2, 16-37.

DOI: https://doi.org/10.5038/2325-484X.3.2.1096

Available at: https://digitalcommons.usf.edu/jacaps/vol3/iss2/2

This Article is brought to you for free and open access by the Open Access Journals at Digital Commons @ University of South Florida. It has been accepted for inclusion in Journal of African Conflicts and Peace Studies by an authorized editor of Digital Commons @ University of South Florida. For more information, please contact digitalcommons@usf.edu. 


\section{Introduction}

This introduction presents the structural causes of conflict in the Rwandan context as well as the statement of the problem under study. Twenty two years after the genocide against Tutsi, Rwanda is a country still recovering from the devastating conflict and genocide.

Historically Rwanda was composed of three social categories namely Hutus, Tutsis and Twas living side-by-side in the same villages without any separate area belonging to one or another; sharing the same culture, same beliefs, and same institutions that constituted the symbols of the unity of the nation. However, the colonial rule considered social groups (Hutu, Tutsi \& Twa) as racial groups and based its rule on their separation and division. The first administrative reform, known as Mortehan reform in 1930, established an Identity card mentioning the racial group. Unfortunately, it is "on this basis with wrong interpretations of the Rwandan identity that the first (1962-1973) and the second (1974-1994) republics built their leadership"(Braeckman C, 1994).

From the early 1960's, the Rwandan leadership established a discriminatory system against the Tutsi group. The governance system was characterized by constant human rights abuse, citizen's rights violation infused with impunity. These divisions were further enforced through the enacting and implementation of laws based on segregation, biased policies, inequality of treatment, and differential access to basic public services. For instance, a quota system of $10 \%$ was applicable for Tutsi group in the administration and schools at all levels. As a consequence, many Rwandans left the country as refugees, settling in neighboring states and further abroad. The type of conflict that undermined the Rwandan society was an ethnic based conflict.

During the 1990's, Rwanda's political instability and conflict was further exacerbated by the country's high levels of poverty. Its fragile relations within the region, and increased political opposition, both within and outside of the country's borders, culminating in military clashes between the regime of President Juvenal Habyarimana and the Rwandese Patriotic Front (RPF). Although efforts to promote peace and end armed conflict appeared to be on track with the signing of the 1993 Arusha Peace Accord, on 4th August 1993 this peace proved fleeting. Instead, violence quickly escalated to a massive scale and the final phase of the genocide claimed over a million lives of Tutsi.

In the aftermath of genocide, Rwanda presented an image of ruins and horror with almost one million of Tutsi slaughtered; two millions of Hutu fled in neighboring countries. Among refugees were ex -FAR, militias, people who have participated in massacres as well as innocent people. Around 120,000 people were already in jail while the judiciary system was completely devastated by genocide. 
Many studies conducted on CSOs in Rwanda recognize "the presence of a dense network of grassroots associations and national non-governmental organizations"(USAID, 2001). Rwandan civil Society organizations, like some other CSOs in sub-Saharan countries, are often criticized for their ambiguous role during different periods of conflicts. During the discriminatory regimes, as mentioned above, CSOs in Rwanda oriented their actions mainly in economical development activities; they aligned their activities on the government's policies and were enslaved to the government's ideology; they didn't see the trap in which the Rwandan society was embarked through the exacerbation of identity-based conflict. This is evidenced by the fact that CSOs were absent in negotiations process of peace in Arusha from 1991 to 1993. Despite the big number and their spread all over the country, they didn't make any impact on the development of the society during this particular critical period.

In the aftermath of genocide, many Civil society organizations were created to deal with new issues consecutive to war and genocide and concentrating on vulnerable groups. They were instrumental in peace building and conflict transformation in the country. However, there is a controversial debate ongoing about their capacities, impacts and legitimacy in regard to their participation in the peace building process. The Rwanda Governance Board, for example, in its recent assessment study on Civil Society Organizations, estimated the level of trust in involvement of CSOs in national reconciliation as $50.55 \%$, and the incidence of corruption within CSOs as 36\% (RGB 2012:9). This poor performance of CSOs in such areas is questionable especially in a war and genocide torn society.

The role played by civil society organizations in conflict and post conflict situations in Rwanda may be analyzed in connection to the broad history of the country, their relationship with the regime on power and external donors as well as their capacity to achieve their respective mission and vision. Thus, the problem under study can be formulated as follows: What have been the role of Civil Society Organizations in conflict and post-conflict situations that affected the Rwandan society?

\section{Theoretical/conceptual framework}

This study is all about the role of Civil Society Organizations in conflict and post conflict situations in Rwanda. The key concepts that need to be defined in this section are Civil Society Organizations, Conflict and Post-conflict situation. The section also presents the theoretical framework that shapes the most important indicators which were investigated to document the role of civil society organizations in conflict and post conflict contexts of Rwanda.

\section{II.1. Conceptual framework}

\section{II.1.1 Civil Society Organizations}

There are different definitions of the concept of Civil Society Organizations depending on the various perspectives of action and analysis. Certain definitions look at the "space occupied" by 
CSOs. The World Bank (2007), for Example, uses the term civil society organizations to refer to "the wide array of nongovernmental and not-for-profit organizations that have a presence in public life and express the interests and values of their members or others, based on ethical, cultural, political, scientific, religious or philanthropic considerations. This definition of civil society, which has gained currency in recent years in academic and international development circles, refers to the sphere outside the family, the state, and the market". This definition tends to limit CSOs in social settings. Others define CSOs referring to the functions they are called upon to fulfill in the society. The Kabusunzu Center defines CSOs as "all these organizations, institutions and active forces which are not part of the state. They have normally no political objectives and generally they have no profit motive and pursue objectives that are of social, cultural, economic, humanitarian or religious character. According to this definition, three main activities characterize the role of CSOs in the society: Empowering citizen for better participation (education); linking citizen to their leaders (mediation); and advocating for their better lives (lobbing)," (Iwacu-ARDES 1993).

Others stress the individuals who make up civil society organizations. The Ministry of Local Administration (MINALOC) which is in charge of CSOs, defines them in terms of members who voluntarily form an association with the objective of promoting the wellbeing of the population in helping it to resolve its problems, to defend its culture, its rights (economic, social and political) and the environment (MINALOC 2006: 5).

Some common characteristics are stressed through different scholars: they are communitybased organizations, their arena is between family, state and market, they are nonprofit oriented, they are separate from the state organs, they express the interests and values of their members, etc (USAID/Rwanda 2001). Therefore, civil society organisations include Civil Society employees associations, professional associations, trade unions, cooperatives, women and youth organizations, community-based organizations, cultural organizations, local non-governmental organizations, umbrella organizations, etc. It also includes saving and credit cooperatives (SACCO), International non-governmental organizations and religious -based organizations.

In Rwanda, the organizations of the civil society are varied in terms of means and capacities. For example, the powerful Catholic Church which manages $60 \%$ of primary and secondary schools and $70 \%$ of health care centers of the country and a local cultural association "indangamirwa" are both members of Civil Society. Consequently, such diversity makes it difficult for them to agree to a common understanding of their role in the society, especially in conflict and post conflict situation. It has also a certain advantage due to the fact that they are strategically located all over the country, provide services in different sectors, have the advantage of being nearer to local communities and they are well placed to be source of reflection and innovative practices.

\section{II.1.2 Conflict situation}


Various scholars have defined conflict and conflict situation. For John Galtung, 1969 conflict is a situation of " direct violence"; for Miall, 2007 "It is an expression of heterogeneity of interests, values and beliefs that arise as new formations generated by social change come up against inherited constraints." ; for Sandole, 1999 "it is any situation in which two or more social entities or parties perceive that they have mutually incompatible goals.", etc. What appears to be a common characteristic is a situation in which the following conditions exist: a conflict situation; conflict behavior; and conflict attitudes and perceptions. In a more analytical way, Simon Fisher and al., 2000 distinguish three periods in a conflict situation: pre-conflict: "The conflict is hidden from general view. There may be tension in relationships between the parties [...]. Confrontation: the conflict has become more open. Relationships between the sides are becoming very strained, leading to a polarization between the supporters of each side. Crisis: In a large-scale conflict, this is the period of war, when people on all sides are being killed. Public statements tend to be in the form of accusations made against the other side(s)".

In Rwanda, the conflict situation lasted long from early 1960s and climaxed in 1994 genocide. It was an identity-based conflict between Hutu and Tutsi which extends to political, economic and social exclusion of Tutsi group. The tentative claim of fundamental rights by Tutsi refugees has given the opportunity to the regime on power to mobilize for their extermination. This long period, from 1960 to 1994 genocide could be considered as a conflict situation that the country went through.

\section{II.1.3 Post Conflict Situation}

The end of direct confrontation following a peace agreement between parties or a total defeat of one part doesn't lead straightforward to a peaceful situation. It is a fragile period because all features of war are still present: tension between parties, aggressive behavior, weapons, etc. Therefore, any incident is likely to relapse into violence (Gerd Junne and Willemijn Verkoren, 2005. Particularly after a civil war, as it is devastating at all levels of life, the tension is still perceptible within the society between groups and individuals.

The post war and genocide situation in Rwanda could be better described by Edward Newman and Albrecht Schnabel, 2002 , who state that: "Once violence ceases, it becomes extremely difficult to re-create the sense of identity and belonging among communities that have experienced political, economic, and socio-cultural breakdown. While it may be possible to impose a sense of order from outside, the sense of community has to grow from within". In fact, the aftermath of genocide was characterized by mistrust and hate between genocide survivors and families of perpetrators, starvation and depravation of a large majority of the population, persistence of divisive ideology, social and psychological vulnerability of a huge number of Rwandan population. Different vulnerable groups included casualties, ex-combatants, widows and orphans were homeless and hopeless. Post conflict situation is a time of management, 
resolution and transformation of conflict. The contribution of all stakeholders including CSOs is needed to overcome such a situation.

\section{II.2 Theoretical Framework}

This section discusses two theories that are used to clarify the role of CSOs in conflict and post conflict situation. On the one hand, the relationship between Civil Society and the liberal economy development and, on the other hand their specific role in democratization process.

\section{II.2.1. Civil Society Organizations and Economic Development}

With the historical development trends of the capitalist market economy the CSOs have an important role to play. Starting from the evidence that: "the capitalist market economy and the social relationship within it have an impact on the empirical world of civil society, creating inequalities and exploitative relationships that weaken or strengthen some groups at the expense of others", Jude Howell and Jenny Pearce 2001:3 assign a role to CSOs: "as an arena of human sociability, where the possibility of hope and change reside, it creates an intellectual and political opening where different actors can criticize and practically address contemporary social problems. In the context of globalization, where the marginalized, poor, and vulnerable need more than ever a space to articulate and defend their interests and where we all need to discuss how our world can meet everyone's needs". As the neoliberal approach of economy claims the self regulation of the market and a minimum role of the state, "the partnerships and dialogue among civil society, business, and government provide a new means of regulation that simultaneously injects a degree of morality into the working of capitalism"(Jude Howell and Jenny Pearce 2001:8). Therefore, "all individuals, through their diverse associations and organizations have the right to contribute to discussions about how to organize their society, deal with its problems, and ultimately define what kind of development is required and desired"(Jude Howell and Jenny Pearce 2001: 13). The economic reconstruction as well as the democratization process and inclusiveness are means of conflict resolution and peace building. CSOs have a great role of education and lobbying to play in this matter.

\section{II.2.2 Civil Society and Democracy}

A certain school of thought (Hall 1995) associates democratization process with the role of civil society organizations. Civil society is a rich social fabric formed by a multiplicity of territorially and functionally based units. The strength of civil society is measured by the peaceful coexistence of these units and by their collective capacity simultaneously to resist subordination to the state and to demand inclusion into national structures. Democracy is a process of promotion of civil rights and fundamental liberties. This cannot be achieved without the existence of a vibrant civil society capable of monitoring the action of the government and 
offering to citizen formal and informal mechanisms of control on one hand and a civil society free from internal and external dependency on the other hand. This needs a strong civil society and a democratic government which foster civil and social rights. The civil society area is considered as a sign of high level of institutionalization of the principle of participation. However, the civil society itself must be of democratic and inclusiveness sensitivity, well structured and efficient. The relationship between civil society and the government are determinant of the role played by its organizations in promoting democratic governance.

These two theories will provide indicators and help to document the role played by CSOs in conflict and post conflict situations in Rwanda.

\section{Methodology}

The main purpose of this study is to describe and to understand the various roles played by CSOs in conflict and post-conflict situations that affected the Rwandan society. The research design that was used is "qualitative approach" in nature even though some quantitative data helped to specify the issues under study. Specifically, the data presented in this chapter were collected through desk research, mixed with results from closed-ended and open-ended questionnaire submitted to selected civil society organizations operating in the areas related to post conflict reconstruction. The total population of the study was composed of civil society organizations operating in Rwanda with emphasis on those that are directly and actively involved in peace and reconciliation effort. Some of them are engaged in peace building and development area; others are intervening in the area of rehabilitation and reintegration of specific groups like genocide survivors, ex-combatants, orphans from HIV/AIDS, etc. Some others are working in various areas resembling: reconciliation, Human rights, good governance and public health. All these areas are characteristics of conflict and post conflict situations. Most of them (73.3\%) are grouped in umbrellas. A purposive sample was selected with consideration of different clusters (Umbrellas) of civil society organizations intervening in the area of conflict management and post conflict reconstruction. 16 national NGOs, 2 International NGOs and 13 Faith based organizations were selected.

For the analysis of quantitative data, we used the appropriate software (Statistical Package for the Social Sciences or SPSS) while qualitative data were processed with appropriate methods of coding, analysis and interpretation.

\section{Presentation of Findings}

This section is divided into three parts: the first one is a presentation of respondents. The second is a presentation of findings of the study following the key roles of civil society in post conflict situation: Empowering citizen for better participation (education); linking citizen to their leaders (mediation); and Advocating for their better lives (lobbing)"( Iwacu-ARDES, 1993). The third part is analysis and interpretation of results. The last chapter is dedicated to a conclusion and recommendations. 


\section{IV.1.Presentation of Respondents}

First, respondents are presented based on the demographic variables: age, sex, and education; secondly, they are viewed through their respective organizations and umbrellas, types of association and areas of interest.

\section{IV.1.1. Age, Sex, and Education}

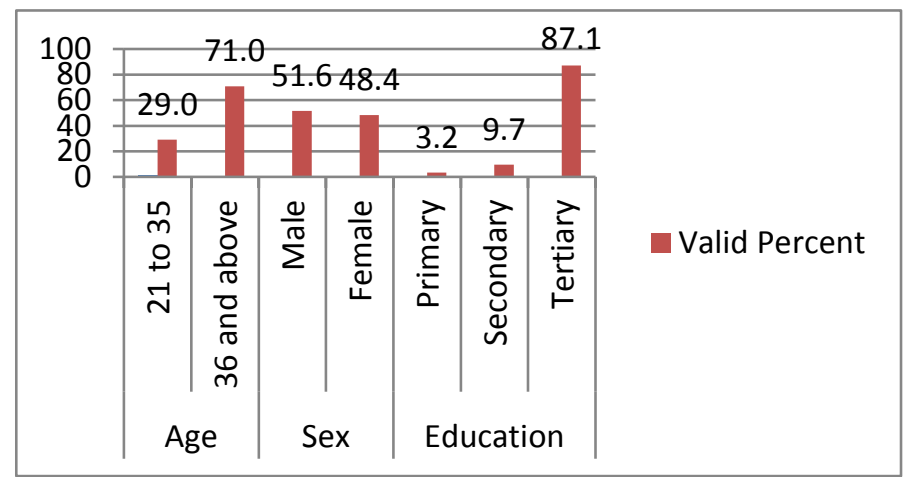

Source: survey 2013

Except the specific associations of youth, the majority of associations' members are adults above 35 years $(71 \%)$. Members of targeted CSOs are qualified from university $(87.1 \%)$. This is due to the nature of activities done by such organizations and most of the time they need specific skills and knowledge that only educated people can have. Another fact to be noted in regard to targeted CSOs is that both men and women are almost equally represented with a slight advantage to male $(51.6 \%$ and $48.4 \%)$.

\section{IV.1.2 Types of Associations}

The Rwandan legal framework of CSOs was revised in 2012 (Official Gazette of the Republic of Rwanda no 10 of March 11 $\left.{ }^{\text {th }}, 2013: 4-7\right)$ due to the diversity of organizations belonging to the framework of non-governmental associations as per the definition provided by the previous law. According to the new organic law, CSOs are divided into three categories: local nongovernmental organizations (LNGOs), international non-governmental organizations (INGOs), and religious -based organizations (RBOs) (Official Gazette no 15 of 17/02/2012). Some slight changes are made in the conception of Civil Society Organization. According to the law governing local NGOs, article 3 specifies that:" national non-governmental organizations are classified into three broad categories in respect to their main objectives and nature of membership: public interest organizations, common interest organization, and foundations". Article 4 authorizes the freedom of dealing in commercial activities. The organ and mechanism of conflict resolution must be included in the statute of a national NGO (Article 6). Art 11 
engages National NGOs in partnership with the government for development. Art 12 stipulates that "the government shall include in its national budget funds meant for supporting national NGOs". Article 30 provides that the supervision of activities and monitoring of the functioning of local NGOs is under the Rwanda Governance Board: "for the purpose of promoting transparency and accountability".

According to the law governing the international NGOs, it is mandatory for an INGO to be public interest oriented in its objectives (art. 2). It shall engage in partnership with the government for development (art.4). The competent authority to grant the registration certificate is the Directorate General of Immigration and Emigration (art.6).

Concerning the law related to religious-based organizations; it is stipulated that "the government and RBOs shall engage in partnership for development" (art.8). The Rwanda Governance Board is the competent organ to grant a registration certificate and to monitor their functioning (art.14). The diagram below presents the repartition of respondents based on the type of their organization.

Table 1: Type of association

\begin{tabular}{|rl|r|r|r|r|}
\hline & Frequency & Percent & \multicolumn{1}{c|}{$\begin{array}{c}\text { Valid } \\
\text { Percent }\end{array}$} & $\begin{array}{c}\text { Cumulative } \\
\text { Percent }\end{array}$ \\
\hline Valid & National & 16 & 51.6 & 51.6 & 51.6 \\
NGO & & & & \\
& International & 2 & 6.5 & 6.5 & 58.1 \\
NGO & 13 & 41.9 & 41.9 & 100.0 \\
FBO & 31 & 100.0 & 100.0 & \\
Total & & &
\end{tabular}

Source: survey 2013

\section{IV.1.3 Belonging to Umbrellas}

Another characteristic of Civil Society Organizations in Rwanda is the tendency to join an umbrella group. Different umbrellas are gathered in a very big entity called "Civil Society Platform" which regulates the relationship between each umbrella and the government and coordinates their activities. According to the results, $73.3 \%$ of our respondents' organizations belong to an umbrella.

\section{IV.1.4 Geographical Area and Domain of Intervention}

CSOs in Rwanda operate mostly at national level. It appeared that $96.8 \%$ of the associations of the study do not target a specific area of the national territory. Even at local level, their 
objectives target the entire country. This idea is complementary to what we stated above that they all tend to belong to a national umbrella group.

This study revealed that some CSOs target a specific group of beneficiaries depending on the type of intervention they do; while $58.1 \%$ target national constituency, $41.9 \%$ of the CSOs involved in this study focus on specific areas.

Despite the common characteristics mentioned above, CSOs in Rwanda are various when it comes to their field of intervention as it is displayed through the table below: $45.2 \%$ are in peace building and development area, 29\% are intervening in the area of rehabilitation and reintegration of specific groups like genocide survivors, ex-combatants, orphans from HIV/AIDS, etc. $19.3 \%$ are working in the area of peace building and Human rights, others are in the field of good governance or public health.

\section{Figure 1: Domain of intervention}

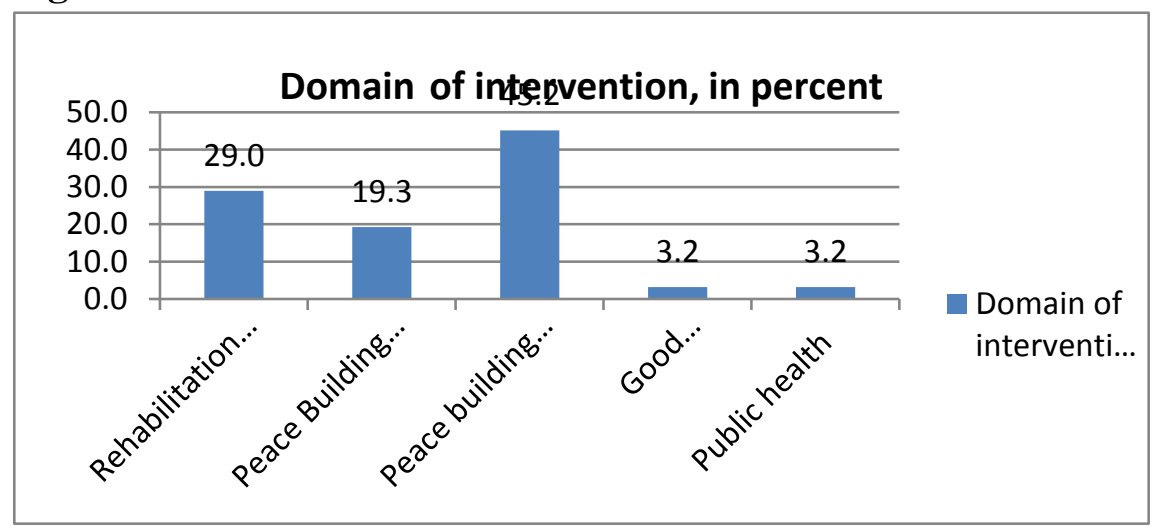

Source: survey 2013

\section{IV.2. Presentation of Findings}

This section presents the data collected from the field with their analysis and interpretation in relation to what other authors wrote on the same topic.

\section{IV.2.1. Resistance to hatred culture}

The first two questions in this study were: To what extent did your organization work to improve inclusiveness during ethnic based rule? The answers showed that the majority of respondents (77.4\%) did not know. Thus, most CSOs that are functioning in Rwanda today were founded after the 1994 genocide and therefore they can't be evaluated on the basis of their past actions since they were not yet founded. However, according to the respondents, even some of the CSOs $(12.9 \%)$ that were functioning did not play any significant role to foster inclusiveness.

The second question was: To what extent was your organization itself undermined by divisionism and ethnic hatred during ethnic based rule? According to the results of the study, the majority $(77.4 \%)$ of organizations that made up our sample was established after genocide and 
therefore this question was somehow non-applicable to them. $12.9 \%$ that were there before genocide confirmed that they were highly affected by divisionism that used to characterize the country's politics.

The next question was: "To what extent is your organization working to improve communication between divided people after genocide?" The response is relatively encouraging because, almost $61.3 \%$ work to improve communication between divided people after the genocide. The National Unity and Reconciliation policy has tasked CSOs to facilitate the mediation between the population and the government, especially concerning the receptivity of the policies related to unity and reconciliation; to collaborate in the healing process of the trauma wounds; to participate to the search for truth on genocidal process, and contribute to the alleviation of poverty, especially in rural area, identified as a serious impediment to unity and reconciliation process (NURC 2007:22-23).

\section{IV.2.2 Advocacy}

The CSOs are supposed to play an important role in policy formulation process. They advocate for policies and actions that represent their constituents' needs; they play a watchdog role, which serves as a check on the power of the government by providing feedback on its performance; and a partnership role, in which CSOs work together with the government on policy implementation. This interaction is effective when CSOs are capable of evidence-based practices through research and analysis of issues. Three questions documented the issue. The first question was: Is your organization used to provide with evidence and analysis to assist the reframing of issues.

Table 2: CSOs used to assist the reframing of issues

\begin{tabular}{|ll|r|r|r|r|}
\hline & & & \multicolumn{2}{c|}{$\begin{array}{c}\text { Valid } \\
\text { Percent }\end{array}$} & $\begin{array}{c}\text { Cumulative } \\
\text { Percent }\end{array}$ \\
\hline Valid & Fery often & 4 & 12.9 & 12.9 & 12.9 \\
& Sometimes & 20 & 64.5 & 64.5 & 77.4 \\
& Rarely & 7 & 22.6 & 22.6 & 100.0 \\
& Total & 31 & 100.0 & 100.0 & \\
\hline
\end{tabular}

\section{Source: survey 2013}

As per the figure above, the great majority of respondents do play a less significant role in reframing public policies. $64.5 \%$ confirmed that they sometimes assist while $22.6 \%$ rarely intervene. The second question was: Is your organization involved in providing evidence and analysis to persuade people to adopt new attitudes and approaches? $61.3 \%$ of the respondents sometimes intervene in transmitting government policies to citizens and $19.4 \%$ rarely intervene. This is also due to the lack of capacity for the majority of CSOs in Rwanda in matters related to how they really serve the population and link them to the government. 
The third question was formulated as follows: At which level does your organization play a key role in building capacity of individuals? The findings show that CSOs highly invest into capacity building to the percentage of $67.7 \%$. The explanation of this involvement is that $45.2 \%$ of our sample is employed in the field of peace building and development as shown in the first section of this chapter. Their role is mainly to empower people with knowledge, skills and values related to peace building and development.

Figure 2: Type of association Vs CSOs used to assist the reframing of issues. cross tabulation

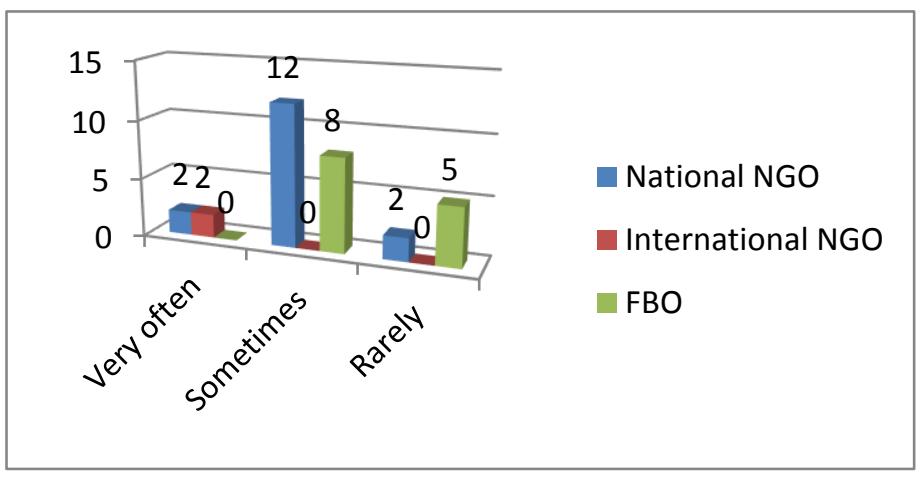

\section{Source: survey 2013}

A cross tabulation between type of association and the assistance in reframing of issues demonstrates that National NGOs and Faith Based Organizations (FBOs) are reluctant to assist the reframing of issues. In the same way, FBOs are rarely invested in providing evidence and analysis to persuade people to adopt new attitudes and approaches?

Table 4: Type of association * CSOs used to persuade adopt new attitude and approach Cross tabulation

\begin{tabular}{|ll|r|r|r|r|}
\hline & & \multicolumn{2}{|c|}{$\begin{array}{c}\text { CSOs used to persuade adopt new } \\
\text { attitude and approach }\end{array}$} & \multirow{2}{*}{} \\
\cline { 3 - 5 } & $\begin{array}{c}\text { Very } \\
\text { often }\end{array}$ & Sometimes & Rarely & \multicolumn{2}{|c|}{ Total } \\
\hline Type of & National & 3 & 12 & 1 & \multicolumn{2}{|c}{16} \\
association & NGO & & & & \\
& International & 2 & 0 & 0 & 2 \\
& NGO & 1 & 7 & 5 & 13 \\
Total & FBO & 6 & 19 & 6 & 31 \\
\hline
\end{tabular}

Source : survey 2013

IV.2.3 Model of inclusiveness and accountability 
A program of conflict resolution is likely to succeed if it is accompanied by social, economic and political measures. Inclusiveness and accountability are keys to overthrow divisive tendencies. As stressed by Ramsbotham and al. 2005:7" We argue for a broad understanding of conflict resolution". The genocide against Tutsi was committed by a government which involved a big number of its citizen in massacres. A series of questions were asked in this regard. Is your organization a model of fostering understanding between divided groups? The results show that they are committed at the rate of $87.1 \%$ to be a model of fostering understanding between divided parties.

To what extent is your organization safe from genocide ideology? The results show that CSOs are highly free from genocide ideology $80.6 \%$. This is a positive sign that CSOs are playing an important role in rebuilding the society. Thus, the most important contribution of CSOs in Rwanda in the process of peacebuilding is to overcome the legacy of ethnic hatred and genocide and to build trust between individuals and groups.

Is your organization a model of accountability in its management? $61.3 \%$ of our respondents esteem that the CSOs in Rwanda may be taken as model of accountability in the management of their organization.

To what extent is your organization free from corruption? According to the respondents, $61.3 \%$ are free from corruption. However different studies done in this last years are more pessimistic about the freedom of civil society from accountability and corruption. The RGB 2012:15 estimated the incidence of corruption in CSOs at $36 \%$ which is very high.

Figure 3: Type of association and internal accountability. cross tabulation

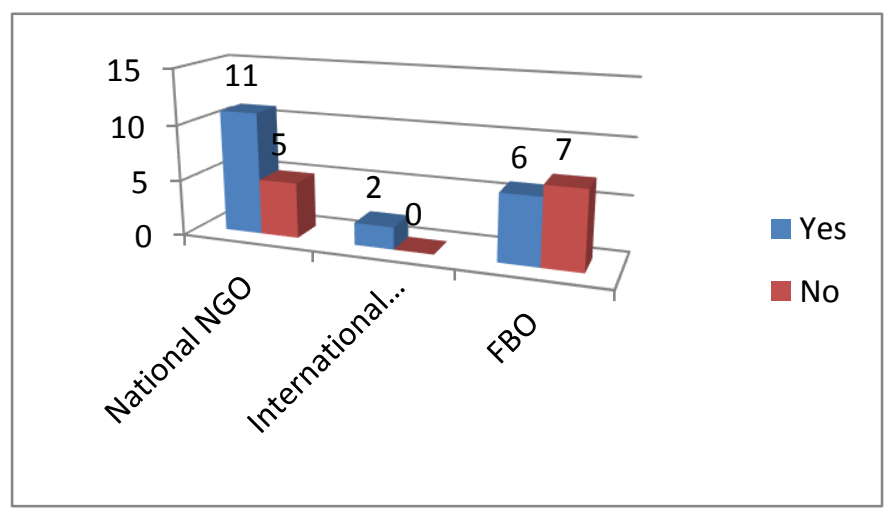

Source: survey 2013

In matters of internal accountability, the FBOs are less performing compared to other CSOs. This means that they are in a weaker position to require from governmental institutions to be accountable.

\section{IV.2.4 Contribution to positive change}


Two assumptions advocate for the consideration of CSOs in the process of reconciliation and peace building: "first, the reconciliation process works best when formal and informal methods are integrated holistically. Second, reconciliation can be used to address wider concerns like poverty, democracy, inclusiveness, etc" (USAID-Rwanda 2001: 9). It is almost difficult to achieve sustainable reconciliation without the active participation of the communities. This is why the consideration of the contribution of CSOs in ongoing changes is of paramount importance.

At which level is your organization contributing to the changes ongoing in Rwanda?

Their contribution is evaluated at $61.3 \%$. : "Considering the Rwandan context, especially the 1994 genocide, the results provided by the Rwanda governance scorecard show that trust among specific groups is one of the factors to be considered when measuring governance. In addition, various institutions have contributed to the reconciliation process in Rwanda. Data collected from different sources reveal that citizen trust local authorities most (85.65\%), followed by institutions of accountability (72.68\%), institutions involved in administration of justice (73.78\%), Media (72.88) and lastly CSOs and FBOs (67.7\%). The contribution of Media, CSOs and FBOs to national unity and reconciliation is still relatively low compared to that of the state institutions" (RGB 2010: 14).

To what extent your organization is improving inclusiveness and participation practices in Rwanda?

The results show that sensitivity to the importance of inclusiveness and participation in post conflict situation is evaluated at $80.6 \%$. It is important to note that the social and economic development is one way of reconciliation after conflict. However, the fair distribution of its fruits to different groups of the population is a means of conflict mitigation. The socio-economic reconstruction has to take appropriate measures to integrate all groups including vulnerable groups by improving their capacities to participate and to access the available benefits of development.

Another question was asked to know to what extent different organizations in Rwanda contribute in changing the behavior of institutions which have an impact on peace. We seek to investigate the sensitivity of CSOs to possible conflict which can arise from the reconstruction process and how they influence different institutions that have a direct impact on the peace process.

Their contribution to change the behavior of institutions that have an impact on peace is restricted to $51.6 \%$. Their capacity to influence the general civic participation in national public policy formulation and implementation is limited. To verify their contribution in the revision process of the law regulating the functioning of Non-governmental associations the following 
question was asked: To what extent did your organization participate in the elaboration process of the new law (Law 4/2012 of 17/2/2012)?

Apart from some $3.2 \%$ who estimate that the participation was high, a big majority $(67.7 \%)$ was not aware of the process. They have been surprised by the new law which changed important features of nonprofit making organizations. The test was conclusive; CSOs in Rwanda are participating at a very little level to public policy making process. This culture is to be improved seriously.

To what extent is your organization advocating for vulnerable groups in Rwanda? $71 \%$ of the respondents are convinced that CSOs are advocating for vulnerable groups at high level. $29 \%$ acknowledge that their contribution is fair. This is one of the strengths of CSOs in Rwanda.

\section{IV.2.5 Sustainability}

One of the most important contributions of CSO in post conflict situation is to facilitate the ownership by the population in general and the beneficiaries in particular concerning the achievement made in different sectors of life in the society. We seek to know at which level the work done by CSOs in peace building is sustainable. The respondents are moderately optimistic. $22.6 \%$ think that the work done by CSOs in peace building is highly sustainable and $64.5 \%$ think it is merely sustainable.

However, a cross cutting perspective shows that for all CSOs in Rwanda, all categories observed, peace building sustainability is not their priority.

Table 6: Type of association * CSOs' peace building sustainability Crosstabulation

\begin{tabular}{|c|c|c|c|c|c|}
\hline & \multicolumn{3}{|c|}{$\begin{array}{c}\text { CSOs' peace building } \\
\text { sustainability }\end{array}$} & \multirow[b]{2}{*}{ Total } \\
\hline & & High & Middle & Low & \\
\hline \multirow{3}{*}{$\begin{array}{l}\text { Type of } \\
\text { association }\end{array}$} & National NGO & 3 & 10 & 3 & 16 \\
\hline & $\begin{array}{l}\text { International } \\
\mathrm{NGO}\end{array}$ & 0 & 2 & 0 & 2 \\
\hline & FBO & 4 & 8 & 1 & 13 \\
\hline Total & & 7 & 20 & 4 & 31 \\
\hline
\end{tabular}

Source: survey 2013

The role of capacity building and education played by CSOs is crucial in ensuring sustainability. This question was directly linked to the following about the most important strength of CSOs in Rwanda in their role of building lasting peace. 
They are closer to their beneficiaries at 53.5\% and their methods of building peace are, among others, education which includes research and training. Despite the fact that there is a huge difference in their capacity and means of working, CSOs in Rwanda are present in both rural and urban areas. The convincing example is given by the faith based organizations which are extended to all over the country even in the remote areas. It is the same with women associations. However, the respondents summarized the weakness of CSOs in Rwanda as follow:

Table 7: Type of association * CSOs' weaknesses Cross tabulation

\begin{tabular}{|c|c|c|c|c|c|c|}
\hline & \multicolumn{4}{|c|}{ CSOs' weaknesses } & \multirow[b]{2}{*}{ Total } \\
\hline & & $\begin{array}{c}\text { Financial } \\
\text { dependency }\end{array}$ & $\begin{array}{c}\text { Poor } \\
\text { governance }\end{array}$ & $\begin{array}{c}\text { Occurence } \\
\text { of } \\
\text { genocide } \\
\text { ideology } \\
\text { cases }\end{array}$ & Other & \\
\hline $\begin{array}{l}\text { Type of } \\
\text { association }\end{array}$ & $\begin{array}{l}\text { National } \\
\text { NGO }\end{array}$ & 9 & 3 & 1 & & 16 \\
\hline & $\begin{array}{l}\text { International } \\
\mathrm{NGO}\end{array}$ & 2 & 0 & $c$ & & 2 \\
\hline & FBO & 6 & 3 & 4 & & 13 \\
\hline Total & & 17 & 6 & 5 & & 31 \\
\hline
\end{tabular}

Source: survey

Financial dependency at $54.8 \%$ and poor governance at $19.4 \%$; other weaknesses highlighted are the occurrence of the genocide ideology, corruption, lack of accountability, and lack of efficiency, etc. A cross tabulation demonstrates that all types of association shows the same weaknesses.

\section{Analysis and Interpretation of results}

This study on the role played by CSOs in conflict and post conflict situation in Rwanda has identified the main characteristics of civil society and their status in the country. This section presents the synthesis of the findings and the contribution of the study in relation to the theoretical framework.

\section{V.1 Fighting against hatred ideology before and after the genocide}

The political regime of the first and second republics was articulated around two main points: democracy is a rule of the majority. Hutu group represents the majority of Rwandan population. Therefore, a Hutu regime is a democratic regime. The exclusion of Tutsi group is done in the name of democratic principles. Fighting exclusion and discrimination was synonymous of opposing democratic rule. Despite the proliferation of associations, the principle of inclusion and participation of all citizens in the political, economic and social arena was not an issue. The 
majority of the associations involved in this study were intervening in developmental areas instead of protecting and promoting fundamental rights. This is why the findings of this study revealed that their impact to improve inclusiveness during ethnic based rule was insignificant $(22.6 \%)$.

The faith based organizations had the institutional capacity to transmit information to all over the country, but they were themselves undermined by ethnic based conflicts. Some priests of the big Catholic Church have been sentenced because of being involved in massacres against Tutsi during the genocide. Just few examples to illustrate: the ICTR sentenced Abbe Seromba of perpetuity penalty. The Gacaca Jurisdictions of Butare sentenced Abbe Sekamana Denis of 19 years. Even now, some priests of Cyangugu Diocese have created a political party based in France which institutionalizes the ideology of hate and division based on ethnic identity (www.igihe.com visited on $12^{\text {th }}$ September 2013).

CSOs that started in the late 1950s played an ambiguous role during and after conflict periods. Some authors are very critical about positions taken by CSOs in Rwanda during the critical context of totalitarian regimes. In his analysis of Rwandan civil society before the genocide, Peter Uvin 1999:5 states that "Although Rwanda had a reputation among donors as having a highly developed and vital civil society, its civil society did nothing to stop genocide"... civil society reflected the country's political and ethnic divisions".

However, some associations intervening in the area of human rights and religious groups tried to denounce the exactions committed by the Habyarimana's regime in vain. For example they voiced the arbitrary detention of Tutsi population after the attack of the country by Rwandan Patriotic Army (RPA) on $1^{\text {st }}$ October 1990. They articulated their disagreement about the trends of divisionism within political parties between what have been called "Hutu power", favorable to the extermination of Tutsi group and "others", the moderate wing since 1992. At the same period, extremists had organized the Hutu militia, Interahamwe, and had started to intensify hate campaigns directed against the Tutsis and alleged Hutu traitors. During conflict situations in Rwanda, CSOs were not able to play a sufficient role in influencing political decisions.

Civil society organizations are normally considered as watchdogs to denounce all kind of injustice and exclusion in the society. When a majority of the population approves the exclusion and discrimination of one part of the Rwandan population as a normal way of living in social, political and economic spheres, we expect from organizations of civil society to push the alarming sound to make people sensitive to discriminatory behavior and practices. But, still, a residual hate against Tutsi is present within some local and international organizations. This undermines the principles under which they base their action in Rwanda. Admitting equal rights for all citizens is a very huge challenge in Rwandan context. The role of CSOs in managing, resolving and transforming conflict in this case is very limited. 
In the aftermath of genocide many organizations have been created in Rwanda to deal with consequences of war and genocide. Some focused on specific aspect of the problem like ARCTRuhuka which addresses the issue of trauma counseling and rehabilitation of people psychologically affected by genocide; NEVER AGAIN which tries to make available the knowledge about genocide and its prevention; Others are focused on specific groups like Ibuka (remember) and AVEGA Agahozo which are dedicated to the rehabilitation of survivors of genocide; UMUSEKE which is concentrated on youth, etc.

They played a very important role in conflict resolution in post genocide period. CSOs gained new insights in their role as champion of inclusiveness and participation. They made great achievements as it has been highlighted in previous lines, but they still have a long way to go in firmly establishing their role in a war and genocide torn society. Having said all that, they are backed by a favorable political environment that promotes unity and reconciliation of all Rwandans and emphasizes the contribution of CSOs in this struggle.

\section{V.2 Effectiveness of CSOs in Rwanda}

Another challenge faced by CSOs in Rwanda is the effectiveness of their interventions. Except International NGOs which have gained the tradition of basing their actions on research and analysis, Local NGOs struggle to follow the same habit. Most projects are started because someone proposes a funding or the government needs a support from civil society and some local organizations are lasting the period of a lifelong of a given project. In short, most of them are incapable of initiating and or promoting any change or protecting their own principles.

Working in conflict and post conflict situations requires actors to develop capacities and skills of analyzing conflicts and conflict resolution approaches. At least four steps articulate the conflict analysis as stressed by Poffenholz, 2010: "1) analysis of the conflict and peace environment, 2) anticipating conflict dynamics and peace building, 3) analyzing the peace building deficiencies defining the envisaged future peace, and 4) specifying the needs of peacebuilding in general or in a particular sector".

The effectiveness of CSOs' interventions depends mainly on their capacity to convince others about the relevance of their actions, advocate for change and build capacity when necessary. However, this cannot be achieved without the existence of a vibrant civil society capable of monitoring the action of the government and offering to citizen formal and informal mechanisms of control in one hand and a civil society free from internal and external dependency in the other hand.

The great majority of CSOs in Rwanda do play a less significant role in reframing public policies. $64.5 \%$ of CSOs involved in this study confirmed that they sometimes assist while $22.6 \%$ rarely intervene. This passive involvement of CSOs in the reframing of public policy is due to the fact that some of them have not yet acquired the habit of effectiveness in their 
practices. In addition, the capacity of CSOs is limited and their interaction with government is ineffective. Empowerment programs of CSOs are therefore important (USAID 2001: 8). The Rwanda Governance Board (RGB, 2012:12) stresses that "Currently, national-level CSOs lack full understanding of their constituents' needs and lack the understanding of policy formulation mechanisms and the skills to analyze data, leaving them unable to serve as effective monitors or to advocate for or against policies". Therefore, the government allocated a budget to strengthening the capacities of CSOs (Art. 12 of Law no 04/2012 of 17/02/2012).

However, one of the characteristics of CSOs in Rwanda after the genocide is that they have been created especially for addressing issues of specific groups. They have been advocating for rights of different vulnerable groups like orphans, widows, and children; at the same time, they have been fostering the well- being of these different categories. Nevertheless, some associations are known to be very dynamic like Pro Femmes Twese Hamwe, Haguruka, AVEGA, Reseaux des Femmes in lobbying for inheritance right for women, gender equality, economic development of women and orphans, trauma counseling, etc.

Despite the new trends of CSOs in Rwanda to strengthen effectiveness and contribute to the development of inclusiveness and participation of all in the life of the nation, they need a serious empowerment initiative to make them relevant and efficient in their capacity of basing their action and intervention on well documented facts and contexts.

\section{V.3 Strengths and Weaknesses of CSOs in Rwanda}

In Rwanda, the civil society organizations are varied in terms of means and capacities. For example, the powerful Catholic Church and a local farmers association are both members of Civil Society. Consequently, such diversity has a certain advantage due to the fact that they are widened all over the country, provide services in different sectors, have the advantage of being nearer to local communities and they are well placed to be the source of reflection and innovative practices.

The most weakness that undermines the action of CSOs in Rwanda is their recurrent double dependency on state in one hand and on International donors in the other hand. How can CSOs be organized and efficient if they do not have means for their ambition? Their dependency to the state weakens their capacity of analyzing the action of the government, taking position vis a vis the policies and ideologies of the government and the way policies are implemented. The lack of independency from International donors makes them accepting conditionality established by the donors even though these may be against their own principles, action and way of understanding. The economic reconstruction as well as the democratization process and inclusiveness are means of conflict resolution and peace building. However, the lack of autonomy for many civil society organizations is taken as "a serious hindrance(...) to enjoy the right to contribute to discussions 
about how to organize their society, deal with its problems, and ultimately define what kind of development is required and desired'(RGB 2012:13).

However, the most challenging aspect of post conflict reconstruction is the urgent need of addressing all problems at all levels, and almost at the same time. The CSOs could be of great importance to promote civic participation and foster empowerment of the grassroots. To achieve this task, they need to be empowered themselves and gain financial and ideological autonomous.

\section{Conclusion and recommendations}

\section{VI.1 Conclusion}

This study was dealing with "the role of CSOs in conflict and post-conflict situations in Rwanda". Its main objective was to describe various roles played by CSOs in conflict and postconflict situations that affected the Rwandan society.

The research methodology that was used is a "qualitative approach" where qualitative techniques of data collection were applied. The total population of the study was composed of civil society organizations operating in Rwanda with emphasis on those that are directly and actively involved in peace and reconciliation effort. Most of them (73.3\%) are grouped in umbrellas. A purposive sample was selected with consideration of different clusters (Umbrellas). 16 national NGOs, 2 International NGOs and 13 Faith based organizations were selected.

According to various definitions of CSOs, three main activities characterize the role they play in the society: Empower citizens for better participation (education); link citizen to their leaders (mediation); and advocate for their better lives (lobbing)" (Iwacu-ARDES 1993).

Two theories contributed to provide indicators and document the role played by CSOs in conflict and post conflict situations in Rwanda. In one hand, as the neoliberal approach of economy claims the self regulation of the market and a minimum role of the state, CSOs have the right to contribute to discussions about how to organize their society, deal with its problems, and ultimately define what kind of development is required and desired"(Jude Howell and Jenny Pearce 2001: 13). In the other hand, Democratic governance is a process of promotion of civil rights and fundamental liberties. This needs a vibrant Civil Society capable of monitoring the action of the government and offering to citizens formal and informal mechanisms of control in one hand and a civil society free from internal and external dependency in the other hand. The economic reconstruction as well as the democratization process and inclusiveness are means of conflict resolution and peace building. CSOs have a great role to play in this matter.

The results of the study showed that the role of CSOs to improve inclusiveness and participation during ethnic based rule was insignificant (22.6\%). The great majority of CSOs in Rwanda do play a less significant role in reframing public policies. $64.5 \%$ confirmed that they sometimes assist while $22.6 \%$ rarely intervene. The capacity of CSOs is limited and their interaction with government is ineffective. However, the sensitivity to the importance of inclusiveness and participation in post conflict situation is evaluated at $80.6 \%$. Concerning sustainability, $22.6 \%$ 
think that the work done by CSOs in peace building is highly sustainable and $64.5 \%$ think it is merely sustainable. The most important strength of CSOs in Rwanda in their role of building lasting peace is: they are closer to their beneficiaries at 53.5\%. CSOs in Rwanda are generally present in both rural and urban areas. The respondents summarized the weaknesses of CSOs in Rwanda as follow: financial dependency at $54.8 \%$, poor governance at $19.4 \%$, occurrence of genocide ideology at $16.1 \%$, and others such as lack of accountability, and lack of efficiency at $9.7 \%$.

\section{VI.2 Recommendations}

At the end of this study I would like to formulate the following recommendations:

To CSOs themselves: They have to be concerned by their place and importance in Rwandan society and to shape their impact in post conflict reconstruction;

To international Organizations: They have to systematically provide support to Local NGOs in terms of capacity building through the platform of civil society in Rwanda;

To researchers: This study has shown the interest of carrying out further researches on specific aspects of CSOs in Rwanda. Just to give an example: CSOs relationship with the Government and its opponents, challenges and opportunities?

\section{References}

Braeckman Colette, (1994), Rwanda, Histoire d'un Génocide, Paris, Fayard.

Constitution of the Republic of Rwanda of 4th June 2003 as amended to date, in Official Gazette, Special no of August 13th, 2008.

Edward Newman and Albrecht Schnabel, (2002), Recovering from civil conflict: reconciliation, peace and development, New York, Frank Cass and Co. Ltd.

Fisher Simon and al., (2000), Working with conflict. Skills and strategies for actions, London, Zed book

Galtung Johan, (1969), Violence, peace and peace research, in Journal of peace research, vol.6, no 3, pp 167-191 
Hall. J, (1995), Civil society, theory, history and comparison, Cambridge, Cambridge University Press

International Alert, (2011), Report of the project evaluation workshop, 23 to 25 August 2011, Kigali,

Iwacu-ARDES,(1993), Table Ronde. La société civile et son organisation dans le développement socio-économique et dans la démocratisation au Rwanda, Rapport de séminaire, Kigali,

Jude Howell and Jenny Pearce, (2001), Civil society and development: A critical exploration, London, Lynne Rienner

Junne Gerd and Verkoren Willemijn, (2005), Postconflict development. Meeting new challenges, London, Lumne Rienner Publishers

Law no 04/2012 of 17/02/2012 governing the organization and the functioning of national nongovernmental organizations, in Official Gazette no 15 of 09/04/2012, p. 31-60.

Law no 05/2012 of 17/02/2012 governing the organization and functioning of international nongovernmental organizations, in Official Gazette no15 of 09/04/2012, p. 61-83.

Law no 06/2012 of 17/02/2012 determining organization and functioning of religious-based organizations, in official Gazette no 15 of 09/04/2012, p. 84-103.

Leedy Paul and Ormrod Jeanne, (2005), Practical research. Planning and design, Upper Saddle River, N.J. Pearson,

Miall H. (2007), Emergent conflict and peaceful change, Basingstoke, Palgrave Macmillan

MINALOC, (2006), National policy on civil society, Kigali

NURC, (2007), National policy on Unity and reconciliation, Kigali,

Organic law no 10/2012 of 15/01/2013 repealing the organic law no 55/2008 of 10/09/2008 governing the non-governmental organizations, in Official gazette no 10 of 11/03/2013

Paffenholz Thania, (2010), Civil society and peacebuilding. A critical assessment, Bouble, Leynne Rienner Publishers

Ramsbotham Olivier, Tom Woodhouse and Hugh Miall, (2005), contemporary conflict resolution. The prevention, management and transformation of deadly conflicts, Cambridge, Polity

Richard Reeve, (2012), Peace and conflict assessment of South Sudan2012, London, International Alert, 
Rwanda Governance Board, (2010), Rwanda governance scorecard 2010, Kigali

Rwanda Governance Board, (2012), concept note on "interfaith conference on the role of FBOs in promoting peaceful cohabitation in the great Lakes Region, Kigali

Rwanda Governance Board, (2012), report of the high level meeting on Joint Action Development Forum (JADF) Program review, Kigali,

Rwanda: Human Rights Watch on the spot over Rwanda, in New times of April 18, 2013, p. 8

Sandole D., (1999), capturing the complexity of conflict : dealing with violent ethnic conflicts of the Post- Cold War Era, London, Frances Printer,

Sénat, Rwanda, (2006), Idéologie du génocide et stratégies de son éradication, Kigali,.

Seruka/Pro-Femmes, (1999), travail de recherche sur le rôle de la femme rwandaise dans les mécanismes de résolution des conflits, Kigali

Shyaka, A., (2006), The Rwandan Conflict, Origin, Development, Exit Strategies, Kigali,

Tobie Aurerien and Masabo Francois, (2012), healing fractured lives: reconciliation and reintegration in Rwanda, London, International Alert,

USAID/Rwanda, (2001), Civil society in Rwanda: Assessment and options, Kigali

USAID/Rwanda, (2001), The Civil Society Fund: A Concept Paper. Draft, Kigali, March 12, 2001

Uvin Peter, (1999), L’aide complice: Coopération internationale et violence au Rwanda, Paris, L'harmattan,

World Bank, (2007), consultations with civil society. A sourcebook working document, New York, World Bank 